\title{
Comparison of a usual heat-transfer-station with a hydraulic modified version under the aspect of exergy saving
}

\author{
Anna Vannahme ${ }^{1}$ Tobias Ramm $^{1}$ Mathias Ehrenwirth ${ }^{1} \quad$ Tobias Schrag $^{1}$ \\ ${ }^{1}$ Institute of new Energy Systems, University of Applied Sciences Ingolstadt, Deutschland, \\ anna.vannahmedthi.de
}

\begin{abstract}
In this paper, a modeling approach for comparing two heat-transfer-stations (HTS) is presented. By comparing a usual HTS with a modified HTS, where the return temperature on primary side of the district heating network (DHN) is used for heating the domestic warm water (DWW), it can be shown that utilizing the return flow of the heating positively contributes to a reduction of temperatures within a DHN and in this way saves exergy. The simulation model is implemented in Modelica.
\end{abstract}

Keywords: $\quad$ heat-transfer-station, hydraulic system, control design, district heating, single-family house

\section{Introduction}

In order to achieve the German government's aims of covering $60 \%$ of gross final energy consumption by renewable energy sources in 2050 (Bundesministerium für Wirtschaft und Energie, 2018), it is necessary to expand DHN and increase the economic efficiency of existing DHN. Especially in rural areas with a low specific heat demand, the economical operation of DHN is challenging. To cope with these challenges, this paper focusses on non-retrofitted single-family homes as heat consumers, which accounts for a high proportion of houses in rural areas. The return temperatures are a decisive factor for reducing heat losses and improve overall efficiency. The hydraulic setup of a HTS has a great impact on the level of return temperatures (Johansson et al., 2009). For this reason, a measurement based and simulative comprehensive investigation of different HTS will be done. The first step in this comprehensive investigation is to simulate and analyse different HTS. A test rig for space-heating systems in residential buildings is currently under development to carry out measurement based investigations of HTS and to validate the simulation model. Later on, this test rig will be combined with Modelica and thus used for Hardware-in-the-loop (HiL) simulation.

In the field of measurement based investigations, the University of Applied Sciences in Munich has investigated HTS for apartment buildings with focus on DWW heating and lowering return temperatures
(Stadtwerke München et al., 2014). Due to associated more complex hydraulic setups, apartment houses are mostly the objects of such investigations (Knierim, 2007; Triesch and Weinmann, 2008; Overhage, 2016). The aqotec GmbH makes a concept proposal for a HTS, where the primary return of DHN from the heating system is used for heating the DWW (aqotec GmbH, 2011). This concept is adopted in this research article and implemented within the simulation model.

In the recent years, modelling of DHN by using Modelica increased (Heissler et al., 2016; Fuchs et al., 2013). Also, HiL simulations with Modelica are currently conducted (Baltzer et al., 2014; Knorr et al., 2016).

As aforementioned, the first steps are to simulate different HTS. Therefore, a usual HTS with a DWW storage is compared with a modified HTS, where the DWW storage is used for further cooling of the primary return of DHN. The question posed in this article is, whether a slight change in the hydraulic system and control strategy can profitably reduce the return temperatures in periods with space heating. The question will first be answered on an exergetic basis and then by analysing the return temperatures. An investigation based on exergy analysis is quite common (Falk, 2018; Sartor, 2017; Mollenhauer et al., 2016; Jentsch, 2018). Also, a Modelica based tool for the dynamic exergy analysis is developed by Sangi et al. (2017).

To introduce the key terms of a district heating system, Figure 1 shows a schematic setup of a DHN, which consists of the following components:

- A central heating station, e.g. a combined heat and power unit or biomass heating plant

- One piping for the warm water feed and one piping for the returning water, which flowing back from the consumers

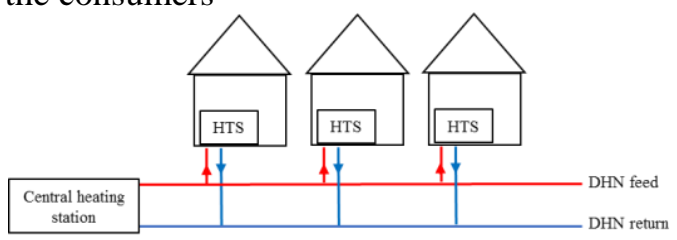

Figure 1. Scheme of a district heating network. 
A HTS is the connection between the DHN and the heating system of a building. Usually, the feed temperature of DHN ranges between $70{ }^{\circ} \mathrm{C}$ and $130{ }^{\circ} \mathrm{C}$ (Dötsch et al., 1998). The heating system of residential buildings has two different load profiles. One is the heating system, (radiator or floor heating system) the other one is the DWW. Table 1 shows the temperature level of each system. Usually, the temperature of the heating circuit is controlled depending on the outdoor temperature. The supply temperature for radiator systems in Table 1 is an orientation value for nonretrofitted buildings. In general, the HTS includes a hydraulic separation between the water in the DHN and the water inside the heating system. In any case, the DWW preparation is separated for hygienic reasons.

Table 1. Supply temperature level of heating systems for residential buildings (Diefenbach et al., 2002; Euroheat \& Power, 2008)

\begin{tabular}{|l|l|}
\hline Heat & Supply temperature level \\
\hline Radiator system & $70{ }^{\circ} \mathrm{C}$ \\
\hline Floor heating & $35^{\circ} \mathrm{C}$ \\
\hline DWW & $60{ }^{\circ} \mathrm{C}$ \\
\hline
\end{tabular}

Typically there exist two types of HTS for singlefamily houses, which can be distinguish in the way of (DWW) preparation (Euroheat \& Power, 2008):

- The indirectly connected substation for instantaneous water heaters (see Figure 2)

- Heaters with warm water storage tank (see Figure 3)

The HTS with instantaneous water heater has two parallel plate heat exchangers. In the case of heat demand, the domestic cold water (DCW) gets heated instantaneously. Therefore, a controller on the primary side is necessary, which receives the actual temperature from the secondary side and adjusts the mass flow on the primary side accordingly. There are different possibilities for controlling this mass flow such as motor-controlled or thermostatic controlled valves. In the first case, a controller gets the input from the temperature sensor and modulates a control signal according to the adjusted set point value, in the second case the thermostatically operated valve operates without the supply of auxiliary energy.

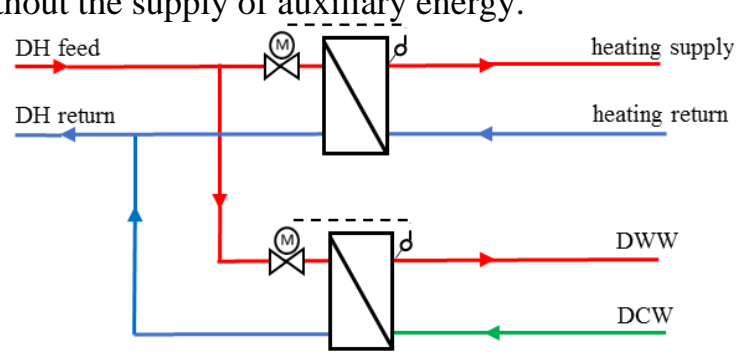

Figure 2. Instantaneous HTS.

There are two ways to design a HTS with a heat storage tank. The storage tank can be connected either on the primary or on the secondary side of the DHN. On the primary side, an external or internal heat exchanger ensures the hydraulic separation from the heat transfer medium of the DHN. Usually, an internal stainless steel pipe is used to charge the DWW storage tank. Furthermore, external heat exchangers may be used to load the heat storage.

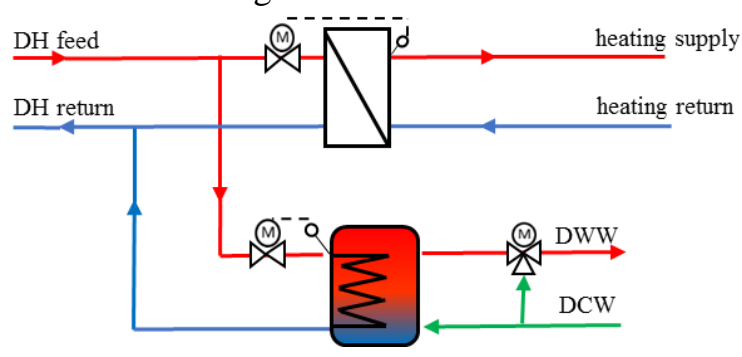

Figure 3. Storage HTS.

While the HTS with an instantaneous water heater requires a high nominal heat flow rate, the HTS with storage has the disadvantage of high return temperatures, unless a special control algorithm for the stratification of the heat storage is implemented. The hygiene is the particular advantage of instantaneous HTS. Storing warm water below $60{ }^{\circ} \mathrm{C}$ increases the formation of Legionella. Therefore, a daily heating up above $60{ }^{\circ} \mathrm{C}$ is also recommended for single-family houses (Deutsche Vereinigung des Gas- und Wasserfaches, 2004). Correlating the DWW demand with an appropriate design of the heat storage ensures the daily exchange of water and thus a hygienic drinkable water.

The integration of a heat storage tank opens various opportunities such as the absorption of the heat from the return of the heating system on the primary side.

Therefore, a modified system of the HTS with storage tank, hereinafter referred to as "Advanced Storage System" (see Figure 4), is proposed. Compared to the conventional setup of a HTS with storage tank, hereinafter called "Basic Storage System" (see Figure $3)$, the advanced configuration is expanded by a threeway-valve (2) (see Figure 4). By means of valves (1) and (2) the charging of the heat storage by a Direct Digital Controller (DDC) is controlled. If the temperature inside the heat storage is too low for satisfying the DWW demand, the storage tank is charged from the DHN feed, valve (1) opens and the output (B) of valve (2) is closed (see Figure 4). The storage tank is charged when a defined temperature is reached in the top layer.

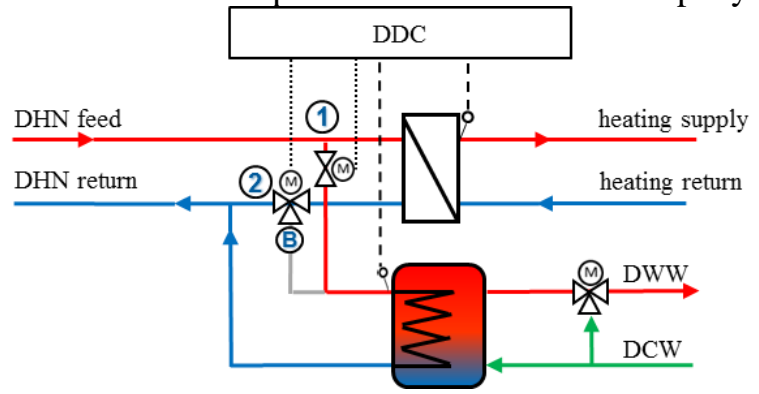

Figure 4. Modified storage HTS charging from DHN feed (case 1). 
If the heat storage tank is charged in the top layer, the lower layers may still be colder than the heating return. This allows transporting the returning mass flow of the heat exchanger through the heat storage tank to cool down further the returning mass flow (see Figure 5). In this case, valve (1) closes and valve (2) opens output (B).

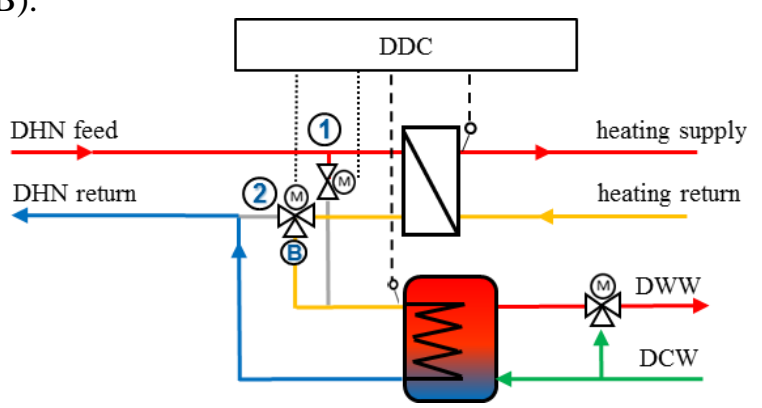

Figure 5. Modified storage HTS in case of return cooling (case 2).

If the lower layers of the heat storage tank have reached the temperature of the heating return, the heating return is routed directly to the return of the network (Figure 6). In this case, valve (1) closes and valve (2) closes output (B).

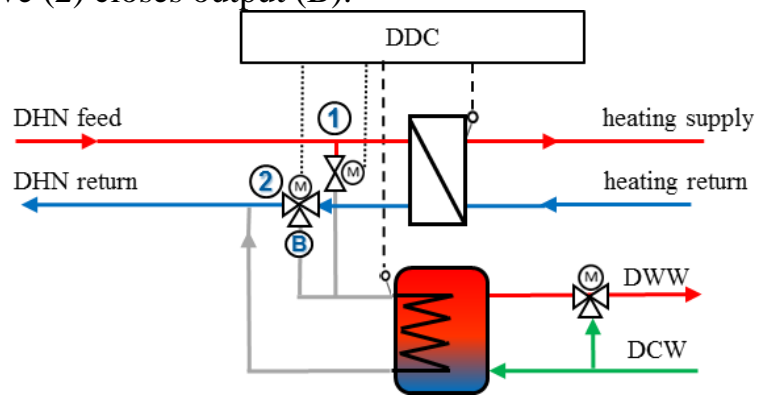

Figure 6. Modified storage HTS in case of fully charged storage (case 3).

\section{Methodology}

For the simulation of the HTS with subsystems like buildings and heating networks in future work, a modular, acausal approach with Modelica language in combination with the software tool Dymola is chosen. The modular approach enables to modify subsystems without the necessity to change other parts of the modeled energy system. The specific acausal modeling approach of Modelica is useful to simulate the HTS later on in a bidirectional way.

For a first estimation of the exergetic saving, a simulation model of both the conventional as well as the more complex HTS with storage tank was proposed. This enables a fair comparison of both systems under the same boundary conditions. The HTS can be tested regarding their function even under extreme conditions, which can be rarely observe in reality.

Figure 7 illustrates a simplified scheme of the modeled HTS. To emulate the DHN, an ideal source and sink with constant pressure as supply and return are used. The return path of heating and DWW is in each case a boundary with a defined temperature and mass flow rate, which emulates the respective heat demand. The value of the mass flow rate comes from a connected table. The tables contain the heat demand profile according to VDI 4655 (2008). All boundary models are taken from the Modelica Standard library (Modelica Association, 2017). On a first estimation, heat losses of the pipes and the heat storage are neglected.

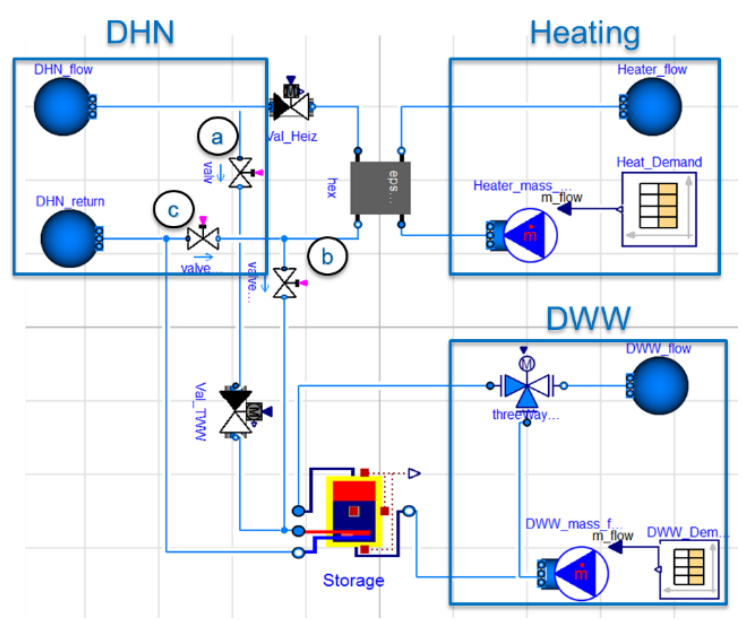

Figure 7. Simplified model of HTS, with return cooling. DHN source and sink (upper left), Heating supply and return (upper right), DWW supply and return (below right), return using control-valve a to $\mathrm{c}$.

The heat exchanger with constant effectiveness is taken from the Modelica Buildings library (Wetter et al., 2014). The effectiveness of the heat exchanger is well-designed with a temperature range of $3 \mathrm{~K}$.

A stratified storage with an internal heat exchanger from buildings library is chosen to simulate the heat storage (Wetter et al., 2014). The control strategy for charging the heat storage tank in the "Advanced Storage System" is shown in Figure 8. The first condition inside the storage tank is that the upper third part should be charged between $50{ }^{\circ} \mathrm{C}$ and $60{ }^{\circ} \mathrm{C}$. If this isn't the case, the storage tank is charged by the DHN feed by opening valve (a) and closing valve (b) until it reaches $60{ }^{\circ} \mathrm{C}$ in the top layer of the ten modeled layers. If the third layer (counted from top) drops below $50{ }^{\circ} \mathrm{C}$, the upper third of storage is recharged, to maintain a sufficient drinking water temperature at the outlet of the heat storage greater or equal $50{ }^{\circ} \mathrm{C}$ (DIN 1988-200, 2012). If the upper third of storage ranges between $50{ }^{\circ} \mathrm{C}$ and $60{ }^{\circ} \mathrm{C}$, the lower part of the heat storage is used for cooling down the returning mass flow of the DHN. Therefore, the temperature within the layers one to seven must be lower than the return from the heater. In this case, valve (b) (see Figure 7) opens and valves (a) and (c) are closed. The storage is completely charged, if the lowermost layer's temperature equals the temperature of the heating return. At this moment valve (c) opens and the other two close. This process is controlled by 
discrete valves, which are opened or closed via the conditions in Table 2.

The comparison of the HTS takes place by ensuring that the "Basic Storage System" has the same state of charge within the storage layers than the "Advanced Storage System". The systems will be compared by the used exergy, the course of the return temperatures and by viewing the quantity of necessary loads from DHN feed.

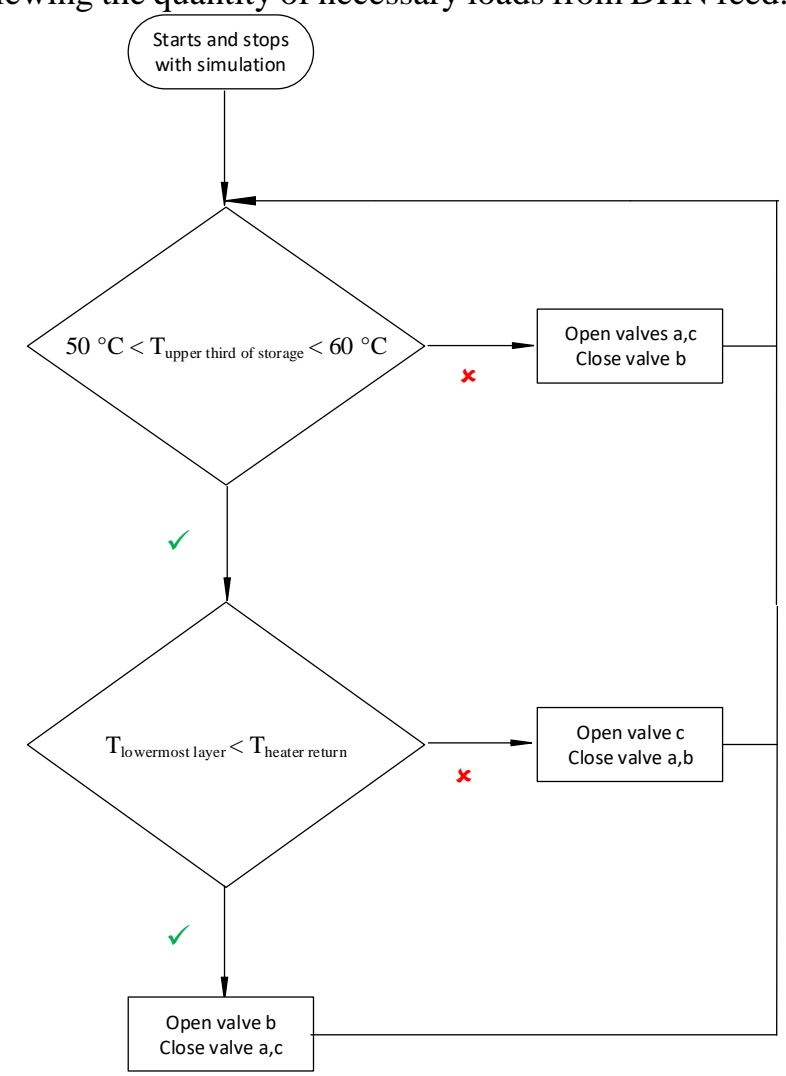

Figure 8. Flow chart for the control strategy.

Table 2. Logic table for control the three cases described in Figure 4 to Figure 6.

\begin{tabular}{|c|c|c|c|}
\hline & \multicolumn{2}{|c|}{ Conditions inside the storage } & \\
\hline & $\begin{array}{l}50^{\circ} \mathrm{C}<\mathrm{T}_{\text {upper }} \\
\text { third of storage }< \\
60^{\circ} \mathrm{C}\end{array}$ & $\begin{array}{l}\mathrm{T}_{\text {lowermost layer }} \\
<\mathrm{T}_{\text {heater return }}\end{array}$ & $\begin{array}{l}\text { Open } \\
\text { valve(s) }\end{array}$ \\
\hline Case 1 & False & True & $\mathrm{a}, \mathrm{c}$ \\
\hline Case 2 & True & True & $\mathrm{b}$ \\
\hline Case 3 & True & False & $\mathrm{c}$ \\
\hline
\end{tabular}

\section{Modeling}

The HTS connects the DHN with the buildings heating demand. In this investigation, an ideal source and sink with constant pressures and a constant DHN supply temperature emulate the DHN. The building's overall demand consists of both, the heating and DWW demand. These demands are calculated from the reference load profiles given by VDI 4655 (2008). The demand profiles are passed as mass flow rate with one minute.
The heating system has a supply temperature of $70{ }^{\circ} \mathrm{C}$ and a return of $55^{\circ} \mathrm{C}$, which is typical for non-retrofitted buildings (Diefenbach et al., 2002). To ensure that the mass flow rate on the primary side of the heat exchanger is high enough to satisfy the heat demand on the secondary side, a valve is controlled by a PID controller, which reading the actual state temperature of the supply heating circuit and checking, if this value reaches the set point temperature. If the temperature is below $70{ }^{\circ} \mathrm{C}$, the valve opens further and if the temperature is higher than $70{ }^{\circ} \mathrm{C}$, the other way round.

The DWW storage is charged via an internal stainless steel pipe. A hysteresis controller is implemented to control the discrete valve (a), which opens for charging the storage from the DHN feed and closes if a defined temperature is reached. In case 2 (see Figure 5) the return flow of the heating process passes through the internal heat exchanger to charge the storage until the lowest layer has an equal temperature. Subsequently the discrete valve (b) is closed by the controller so that the return flow of the heating process flows directly into the DHN return.

On the secondary side of the storage, an outlet temperature of at least $50{ }^{\circ} \mathrm{C}$ is required, as mentioned above. To avoid scalding, the set point temperature for the DWW is chosen $43{ }^{\circ} \mathrm{C}$ oriented on the recommendation DIN EN 806-2 (2005). Therefore a three-way-valve from the IDEAS library (Jorissen et al., 2018) is implemented, which mixes the ten-degree DCW (Baumgarten et al., 2014) with the warm water leaving, to mix the DWW temperature of $43^{\circ} \mathrm{C}$.

\section{Simulation}

The simulation model was fed with the parameters according to Table 3. The parameters for the DHN, represent a small network, which found often in rural areas. The pressure difference depends on the number of consumers and the extension of the DHN. Thus, a pressure difference of one bar is assumed (FairEnergie, 2015). The heating requirements are based on a nonretrofitted four person single-family house with $140 \mathrm{~m}^{2}$ floor area and a specific heating demand of $100 \mathrm{kWh} / \mathrm{m}^{2} \mathrm{a}$ (Dott et al., 2013). The DWW heat demand is base on a specific value of $500 \mathrm{kWh} / \mathrm{a}$ per person stated in VDI 4655 (2008). The DWW storage is usually designed for 301 to 401 per person and day, so that once a day the content is fully consumed and refilled. For an optimal heat transfer, the internal stainless steel pipe is designed over the whole height of the storage tank.

The control was implemented as shown in the flow chart in Figure 8. A verification of the "Advanced Storage System" is given by analysing the correct switching of the valves (a) to (c) (see Figure 7). The correct function of the PID controller is checked by observe the actual and set point temperatures. At a feed temperature of $80^{\circ} \mathrm{C}$ the return temperatures ranging 
between $55^{\circ} \mathrm{C}$ and $60{ }^{\circ} \mathrm{C}$ for the both systems is plausible. The validation should be done on a laboratory test rig, which is outlined in detail below.

Table 3: Simulation parameters for the DHN, HTS and control.

\begin{tabular}{|l|l|r|}
\hline $\begin{array}{l}\text { Model } \\
\text { component }\end{array}$ & Parameter & \multicolumn{2}{|l|}{ Value } \\
\hline $\begin{array}{l}\text { District } \\
\text { heating }\end{array}$ & Feed temperature & $80{ }^{\circ} \mathrm{C}$ \\
\hline & $\begin{array}{l}\text { Pressure } \\
\text { source/sink }\end{array}$ & 5,4 bar/4,4 bar \\
\hline $\begin{array}{l}\text { Heat } \\
\text { exchanger }\end{array}$ & Effectiveness & $70{ }^{\circ} \mathrm{C}$ \\
\hline Heating & Supply temperature & $55^{\circ} \mathrm{C}$ \\
\hline & Return temperature & $43{ }^{\circ} \mathrm{C}$ \\
\hline DWW & Desired temperature & 1501 \\
\hline $\begin{array}{l}\text { DWW } \\
\text { Storage }\end{array}$ & Volume & $1,4 \mathrm{~m}$ \\
\hline & Height & $20^{\circ} \mathrm{C}$ \\
\hline & T_initial & $60{ }^{\circ} \mathrm{C}$ \\
\hline $\begin{array}{l}\text { Storage } \\
\text { charge } \\
\text { Controller }\end{array}$ & Charge temperature & \\
\hline & $\begin{array}{l}\text { Discharge } \\
\text { temperature }\end{array}$ \\
\hline
\end{tabular}

\subsection{Results}

The results were analysed for a period of ten winter days based on exergy. Exergy is the part of the total energy of a system that can do work when placed in the thermodynamic equilibrium with its environment.

The determination of the exergy $\mathrm{E}$ is based on the exergy factor and the integrated heat flow (1). To compare the used exergy correctly, the status of both heat storages has to be determined after simulation.

Amount of used exergy E:

$$
E=f_{E x g} \cdot \int_{t_{1}}^{t_{2}} \dot{Q} d t
$$

where:

\section{$f_{\text {Exg }}:$ Exergy factor \\ $\dot{Q}: \quad$ Heat flow in $\mathrm{kW}$}

The computation of the exergy factor is done using the equation (2), because the temperatures in the period under review are changing. The equation is based on the approach proposed by Bargel (2010):

$$
f_{\text {Exg }}=1-\frac{T_{\text {amb }}}{T_{\text {flow }}-T_{\text {return }}} \cdot \ln \left(\frac{T_{\text {flow }}}{T_{\text {return }}}\right)
$$

where:

$T_{a m b}: \quad$ Ambient temperature $=293.15 \mathrm{~K}$

$T_{\text {flow: }}$ : Flow temperature in $\mathrm{K}$

$T_{\text {return }}$ : Return temperature in $\mathrm{K}$
The saved exergy with the "Advanced Storage System” in comparison to the „Basic Storage System” correlates to a saving of $83 \%$ with respect to the DWW demand. This finding matches the observation of the quantity of necessary charging cycles from DHN feed (see Figure 9). In other words, almost the whole exergy needed for DWW can be covered by the heating return.
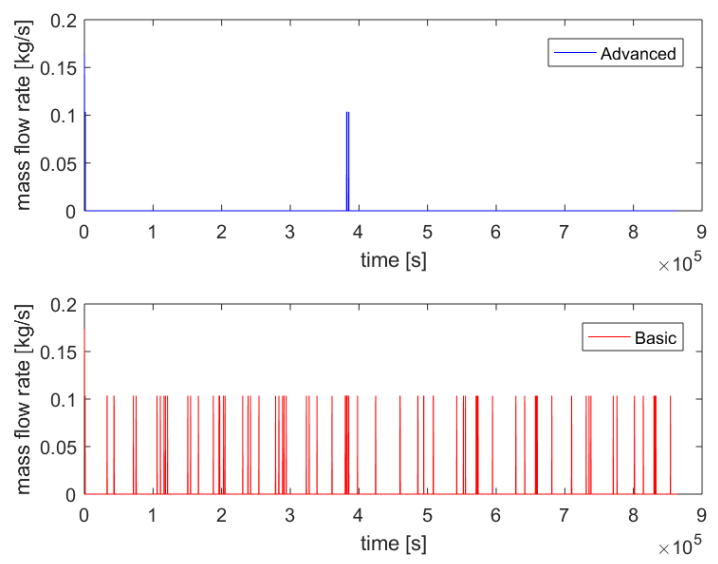

Figure 9. Quantity of charging from DHN feed.

Figure 9 depicts that the "Advanced Storage System" is loaded only three times by DHN feed. The first time at the beginning (as the storage temperature has a initial temperature of $20^{\circ} \mathrm{C}$ ), the second and third time in quick succession during a high DWW demand.

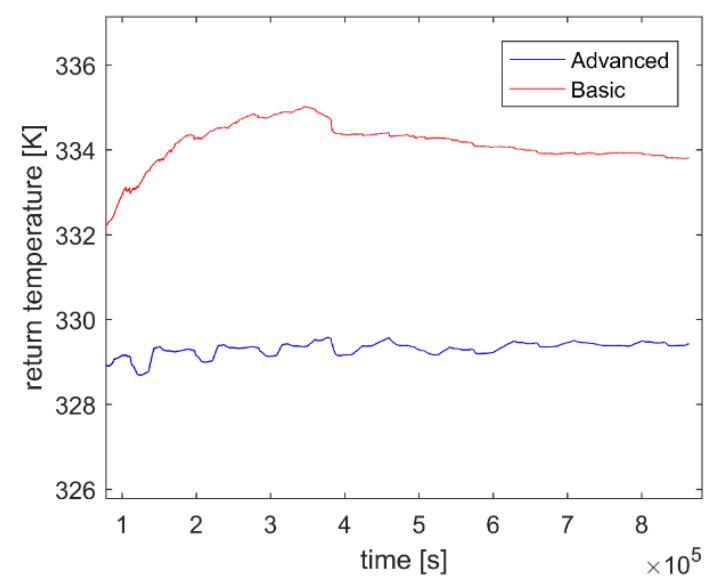

Figure 10. Comparison of averaged return temperatures. The average is weighted by the mass flow rate.

Figure 10 represents that the return temperature of the "Advanced Storage System" is approximately $5{ }^{\circ} \mathrm{C}$ lower compared to the return temperature of the "Basis System". As the mass flow rates are temporarily different, the return temperatures are calculated like written in equation (4). That is why the course of the return temperatures at Figure 10 becomes more and more stable.

$$
T_{\text {return }, n}=\frac{\sum_{i}^{n}\left(T_{\text {return }, i} \cdot \dot{m}_{\text {return }, i}\right)}{\sum_{i}^{n} \dot{m}_{\text {return }, i}}
$$

where: 


$\begin{array}{ll}n: & \text { current simulation step } \\ i: & 1 \text { to } \mathrm{n}, \text { with step }=1 \\ T_{\text {return }, n}: & \text { Return temperature at current } \\ & \text { simulation step in K } \\ T_{\text {return }, i}: & \text { Return temperature at simulation step } \\ & \text { i in K } \\ \dot{m}_{\text {return }, i}: & \text { Mass flow rate at simulation step i } \\ & \text { in } \mathrm{K}\end{array}$

\section{Discussion}

As mention above, the results hold for non-retrofitted buildings with a high heating demand and a high supply temperature for the heating system. The results indicate a significant saving of exergy, because in case of DHN it cumulates. A reduced mass flow rate drawn from DHN is also an advantage of the "Advance Storage System" and it is the reason for the decreased need of exergy. Furthermore, this result is achieved for a welldesigned heat exchanger with a temperature difference of $3 \mathrm{~K}$. If the heat exchanger has a lower effectiveness, the return temperature has more than $58^{\circ} \mathrm{C}$, so that the maximum storage tank temperature of $60^{\circ} \mathrm{C}$ could be reached solely by return cooling. In this case, more exergy from the heating return is available. For a more realistic estimation of the advantages of the "Advanced Storage System", the models should be simulated by using a heat exchanger with a realistic, non-constant effectiveness.

\section{Outlook}

One of the next steps will be the examination of the system behavior and system efficiency in case of a higher resolution of the input data, e.g. $10 \mathrm{~s}$, and therefore a more realistic representation of the DWW demand. Furthermore, both the heat losses of the storage and a realistic model of the pipes should be included. The objective to decrease return temperature by means of HTS will be pursued as follows:

First, more HTS will be investigated, e.g. a HTS with DWW storage tank in comparison with a HTS with instantaneous DWW heat exchanger application. A second example is given by the HTS shown in Figure 11. A HTS with storage offers the opportunity to integrate a decentralised heat source in a low temperature district heating network (LTDHN), which have usually feed temperatures of $40^{\circ} \mathrm{C}$. Thus, it should be investigated whether second heat sources such as a heating rod connect with a photovoltaic array, solar thermal collectors or a stove could be of use for the realization of a LTDHN. This HTS, consisting of a storage with a volume of $1 \mathrm{~m}^{3}$ for single-family houses, is charged by LTDHN. Therefore, the solar thermal system raises the temperature for the DWW demand. The thermal stratification system provides a temperature-dependent stratification of the heating return.

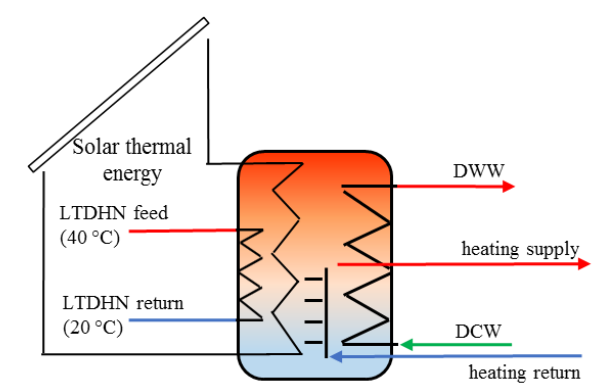

Figure 11. HTS with storage for heating and DWW

After the simulative investigation of different HTS, a measurement based investigation will be performed on a currently developed test rig. As a result, the simulation models of the HTS will be validated. Later on, this test rig for space-heating systems in residential buildings will be extended to a HiL simulation as shown by Baltzer et al. (2014). The software simulation of buildings will also be embedded into the HiL simulation. This is one reason to pursue the concept of a digital twin, e.g. done for the Rooftop building in the field of building and equipment simulation by NytschGeusen et al., for a residential building. This allows a testing of the HTS under realistic boundary conditions and alternating user behavior.

\section{References}

aqotec GmbH (2011), "Ratgeber zur Optimierung der Sekundäranlage beim Fernwärmeabnehmer", Leitfaden 2011.

Baltzer, S., Lichius, T., Gissing, J., Jeck, P., Eckstein, L. and Küfen, J. (2014), "Hardware In The Loop Simulation with Modelica - A Design Tool for Thermal Management Systems", in Proceedings of the 10th International Modelica Conference, March 10-12, 2014, Lund, Sweden, March 10-12, 2014, Linköping University Electronic Press, pp. 401-408. doi:10.3384/ecp14096401.

Bargel, S. (2010), "Entwicklung eines exergiebasierten Analysemodells zum umfassenden Technologievergleich von Wärmeversorgungssystemen unter Berücksichtigung des Einflusses einer veränderlichen Außentemperatur", Dissertation, Fakultät für Maschinenbau, RuhrUniversität Bochum, Bochum, 2010.

Baumgarten, C., Rechenberg, J., Richter, S., Chorus, I., Vigelahn, L. and Schmoll, O. (2014), Wassersparen in Privathaushalten: sinnvoll, ausgereizt, übertrieben?: Fakten, Hintergründe, Empfehlungen, Umweltbundesamt, Dessau-Roßlau.

Bundesministerium für Wirtschaft und Energie (BMWi) (2018), "Sechster Monitoring-Bericht zur Energiewende. Die Energie der Zukunft", Berichtsjahr 2016.

Deutsche Vereinigung des Gas- und Wasserfaches (2004), Trinkwassererwärmungs- und Trinkwasserleitungsanlagen: Technische Maßnahmen zur Verminderung des Legionellenwachstums; Planung, Errichtung, Betrieb und Sanierung von TrinkwasserInstallationen, DVGW-Regelwerk / Technische Regel Arbeitsblatt W, Vol. 551, April 2004, Wirtschafts- u. 
Verlagsges. Gas und Wasser mbH; DVGW Deutscher Verein des Gas- und Wasserfaches e.V, Bonn.

Diefenbach, N., Loga, T., Born, R., Großklos, M. and Herbert, C. (2002), "Energetische Kenngrößen für Heizungsanlagen im Bestand. Eine Untersuchung im Auftrag des Ingenieurbüros für energieeffiziente Gebäudetechnik Ventecs, Bremen".

DIN 1988-200 (2012), Technische Regeln für TrinkwasserInstallationen <TRWI>: Technische Regel des DVGW, Deutsche Norm, Vol. 1988,200, Stand: Mai 2012, Beuth, Berlin.

DIN EN 806-2 (2005), Planung, Deutsche Norm: EN, 806-2, Deutsche Fassung EN 806-2: 2005, Beuth Verlag GmbH, Berlin.

Dötsch, C., Taschenberger, J. and Schönberg, I. (1998), Leitfaden Nahwärme, Stuttgart.

Dott, B.R., Haller, M.Y., Ruschenburg, J., Ochs, F. and Bony, J. (2013), "The Reference Framework for System Simulations of the IEA SHC Task 44/HPP Annex 38. Part B: Buildings and Space Heat Load", A technical report of subtask C. Report C1 Part B. doi:10.13140/2.1.2221.4727.

Euroheat \& Power (2008), "Euroheat \& Power. Guidelines for District Heating Substations".

FairEnergie (2015), “Technische Anschlussbedingungen Fernwärme Heizwasser (TAB-HW) für den Anschluss an die Fernwärmenetze der FairEnergie GmbH".

Falk, P.M. (2018), "Evaluation of district heating systems based on exergy analysis. Bewertung von Nahwärmenetzen basierend auf Exergieanalyse", Fachbereich Maschinenbau, Technische Universität Darmstadt, 2018.

Fuchs, M., Dixius, T., Teichmann, J., Lauster, M., Streblow, R. and Müller, D. (2013), "EVALUATION OF INTERATCTIONS BETWEEN BUILDINGS AND DISTRICT HEATING NETWORKS", 13th Conference of International Building Performance Simulation Association, Chambéry, France, August 26-28, pp. 96103.

Heissler, K.M., Franke, L., Nemeth, I. and Auer, T. (2016), "Modeling low temperature district heating networks for the utilization of local energy potentials", Bauphysik, Vol. 38 No. 6, pp. 372-377. doi:10.1002/bapi.201610038.

Jentsch, A. (2018), "Kalte Nahwärme als Zukunftsoption? Exergie-basierter Vergleich von Nahwärmenetzen", BWK: Das Energiemagazin, No. 70/6, pp. 12-13.

Johansson, P.-O., Lauenburg, P. and Wollerstrand, J. (2009), IMPROVED COOLING OF DISTRICT HEATING WATER IN SUBSTATONS BY USING ALTERNATIVE CONNECTION SCHEMES, 22nd International Conference on Efficiency, Cost, Optimization Simulation and Environmental Impact of Energy Systems, August 31September 3, 2009, Foz do Iguacu, Brazil, Sweden.

Jorissen, F., Reynders, G., Baetens, R., Picard, D., Saelens, D. and Helsen, L. (2018), "Implementation and verification of the IDEAS building energy simulation library", Journal of Building Performance Simulation, Vol. 11 No. 6 , pp.

$669-688$. doi:10.1080/19401493.2018.1428361.

Knierim, R. (2007), "Rücklauftemperatur: Ungehobener Schatz für Versorger und Kunden. Weitere Erlöse aus ungenutzter Wärmeenergie.”, EuroHeat\&Power, Vol. 2007 No. 3, 56-62, 64-65.
Knorr, M., Schinke, L., Beyer, M., Seifert, J., Mehrfeld, P. Nürenberg, M. Huchtemann, K., Müller, D. and Riedesser, F. (2016), "INSTATIONÄRE ENERGETISCHE BEWERTUNG VON WÄRMEPUMPEN- UND MIKRO-KWK-SYSTEMEN - SIMULATION UND EMULATION", TU Dresden, RWTH Aachen, Universität Stuttgart, Dresden, Aachen, Stuttgart, 2016.

Modelica Association (2017), "Modelica - A Unified ObjectOriented Language for Systems Modeling. Language Specification", Version 3.4.

Mollenhauer, E., Christidis, A. and Tsatsaronis, G. (2016), "Evaluation of an energy- and exergy-based generic modeling approach of combined heat and power plants", International Journal of Energy and Environmental Engineering, Vol. 7 No. 2, pp. 167-176. doi:10.1007/s40095-016-0204-6.

Nytsch-Geusen, C., Kaul, W. and Kharaz, S., "DER DIGITALE ZWILLING IN DER ENERGETISCHEN GEB ÄUDE-

UND ANLAGENSIMULATION", in BauSIM2018 - 7. Deutsch-Österreichische IBPSA-Konferenz 26.-28. September 2018, $\quad$ pp. 311-318. doi:10.5445/IR/1000085743.

Overhage, A. (2016), "Maßnahmen zur Erreichung niedriger Rücklauftemperaturen. Einflussmöglichkeiten von Nutzern und Energieversorgungsunternehmen", $A G F W$ Seminar: Maßnahmen zur Erreichung niedriger Rücklauftemperaturen.

Sangi, R., Müller, D., Thamm, A. and Jahangiri, P. (2017), "Dynamic exergy analysis - Modelica-based tool development: A case study of CHP district heating in Bottrop, Germany", Thermal science and engineering progress TSEP, Vol. 4 No. RWTH-2018-221637. doi:10.1016/j.tsep.2017.10.008.

Sartor, K. (2017), "Simulation Models to Size and Retrofit District Heating Systems", Energies, Vol. 10 No. 12, p. 2027. doi:10.3390/en10122027.

Stadtwerke München, Hochschule für Angewandte Wissenschaften München and Ebert-Ingenieure (2014), "Breitenanwendung von Niedertemperatur-Systemen als Garanten für eine nachhaltige Wärmeversorgung. LowEx-Systeme Abschlussbericht zum Forschungsvorhaben: LowEx-Fernwärme-Systeme im Rahmen des Förderkonzeptes EnEff:Wärme - Forschung für energieeffiziente Wärme- und Kältenetze". doi: $10.2314 / \mathrm{GBV}: 856917435$.

Triesch, F. and Weinmann, E. (2008), "Nutzen innovativer Anschlussanlagen für den Fernwärmekunden. Reduzierung der Rücklauftemperatur.", Euroheat \& Power, No. 4, 78-80,82,84-88,90.

VDI 4655 (2008), Referenzlastprofile von Ein- und Mehrfamilienhäusern für den Einsatz von KWK-Anlagen, VDI-Richtlinien, Vol. 4655, Mai 2008, Beuth, Berlin.

Wetter, M., Zuo, W., Nouidui, T.S. and Pang, X. (2014), "Modelica Buildings library", Journal of Building Performance Simulation, Vol. 7 No. 4, pp. 253-270. doi:10.1080/19401493.2013.765506. 
Comparison of a usual heat-transfer-station with a hydraulic modified version under the aspect of exergy saving 